\title{
Crisis of Solidarity in the European Union-No More Dreams of Europe's Competitive Advantage?
}

\author{
Renata Mieńkowska-Norkienè \\ Institute of Political Science of the University of Warsaw, Warsaw, Poland \\ Business and Media School of the Mykolas Romeris University of Vilnius, Vilnius, Lithuania
}

\begin{abstract}
The European Union has been experiencing the whole set of serious crises undermining European integration. The most important ones have been: financial and economic crisis, immigration crisis, crisis of nationalistic radicalization, Brexit, crisis of security caused by terrorism, strengthening of the Islamic State (ISIS), and destabilization of regions around Europe (mainly in the Middle East). The main thesis of this article is that all of them have weakened not only the EU as a whole but also the Member States. This has caused serious consequences being the main topics of this analysis, namely, (1) the value of solidarity lying upon the European integration concept being challenged by the crises; and (2) undermining by the crises the EU's pursuit of achieving the competitive advantage, stated in the strategy Europe 2020. The lack of solidarity is strongly visible in the EU Member States' differentiated attitudes towards the crises the EU has been facing. The paper will focus on analysis of solidarity in the light of intergovernmental approach supported by constructivism. The main research questions are: (1) To what extent have the EU crises strengthened the intergovernmental approach in the EU integration? (2) How has the meaning and scope of the solidarity as the main EU value changed over time in the EU's citizens perception due to the EU crises? (3) To what extent have strong intergovernmental approach and instrumentalization of the solidarity value influenced pursuit for competitive advantage in the EU? (4) Does solidarity have a potential to contribute to efficient reform of the EU leading to strengthening its striving for competitive advantage in the future? The main research approach is intergovernmentalism while the dominating methods are a process-tracing supported by a systemic method. The main conclusion of the article is necessity for redefining the rule of solidarity in order to efficiently strive for competitive advantage.
\end{abstract}

Keywords: EU competitive advantage, EU Member States, strategy europe 2020, European solidarity, intergovernmentalism, process-tracing method

\section{Introduction}

The European Union has been facing numerous crises since 2008. Beginning with financial and economic crisis having resulted in deep Eurozone difficulties and general economic problems in almost all EU Member States, through migrants crisis undermining the Schengen cooperation, challenging the EU's external relations, causing radicalization of nationalistic attitudes in the EU Member States' societies until loosening integration ties

Renata Mieńkowska-Norkienė, professor, Institute of Political Science of the University of Warsaw, Warsaw, Poland; Business and Media School of the Mykolas Romeris University of Vilnius, Vilnius, Lithuania.

Correspondence concerning this article should be addressed to Renata Mieńkowska-Norkienė, 19 Mazowiecka str., PL-05-077 Warsaw Wesoła, Poland. 
among the Member States having led to Brexit, the EU, and the Member States have undertaken numerous activities pointed towards defeating the crises. It is, however, necessary to admit that the measures of defeating the EU crises have not been efficient and it seems that even the economic crisis (which is considered to be over) has not been properly tackled when taking into consideration some of its hitherto consequences. The questions of the scope and the consequences of the crises in the EU have caused not only numerous political debates in the whole EU but also scientific debates and in-depth analyses of the main topics related to it. Explaining the causes, the scope and the measures to fight the crises have become the ambition of numerous scientists in order to formulate recommendations for decision-makers in the future.

Each of these crises has shifted the EU towards intergovernmentalism-forcing even the strongest proponents of federalism as a finalité politique of the EU to revise their approach towards this concept (Faiola \& Birnbaum, 2012). The above mentioned shift has been both a result of weakening position of the EU non-intergovernmental institutions (having been strengthened constantly until 2008) (Marks, Hooge, \& Blank, 1996) as well as a consequence of a necessity for prompt actions of richer EU Member States to support poorer Member States - endangered by all above mentioned types of crises (Moravcsik, 2012). Solidarity as a value lying upon the EU construction has served as an ethical explanation for the "rescue measures" applied in the framework of this specific support, however, it has been also instrumentally used for political purposes in almost every Member State. This has become one of the main problems of the recent state of the European integration as well as of political consequences of the crises leading to more intergovernmental approach towards European integration, more interest in limiting competences of the EU, less responsibility for the decisions on European level. For example, in financial and economic crisis, solidarity was used by Greece to require support from other Eurozone states (particularly Germany) while in migration crisis, it is Germany (but also Greece) that expect solidarity from other EU Member States in accepting refugees and migrants having flooded in extreme numbers to these countries (ekathimerini.com, 2016). The crisis of security after numerous terrorist attacks in Belgium and France has led to accusations towards the EU in various Member States (just to mention Poland) and deep concerns regarding ability of the EU to answer these huge security challenges. Both above-mentioned crises, namely, the security crisis and the immigration crises, have recently been escalated by the events in Turkey after unsuccessful coup d'etat. Turkey's shift towards restoration of death penalty, imprisonment of hundreds of policemen, public prosecutors, judges, and stronger control over freedoms of citizens put into question further efficient cooperation of Turkey and the EU regarding preventing illegal immigration to Europe and Turkey's ambitions to more strongly cooperate with the EU in the future (Euronews.com, 2016). Each type of the crises recently faced by the EU has required different types of supporting actions, each of them has also challenged the value of solidarity in the EU to a different extent (Raspotnik, Jacob, \& Ventura, 2012). Furthermore, devoting energy of the EU institutions and Member States to managing ad-hoc crises has led to a lack of actions strengthening their competitive advantage foreseen in the Europe 2020 strategy. This, together with growing intergovernmental approach supported by stronger and stronger position of Germany in taking the most important decisions regarding fighting the EU crises, has resulted in deep crisis of the EU values, in questioning of the EU legitimacy, finally, in decreasing support for the EU in the Member States and their societies. The structure of the paper will embrace the literature review, explanation of the methodology, and main scientific approaches to the problems concerned, analysis of the research results, finally presentation of the main discussion topics, and the paper conclusions. 


\section{Literature Review}

"Everybody speaks about solidarity. But they all have their own dictionary" (The Economist, 2015).

Reference to solidarity is expressed already in the Preamble of the Lisbon Treaty (both of Treaty on European Union and Treaty on Functioning of the European Union), however, it is pointed out as one of the basic EU values in Art. 2, Art. 3 of the Treaty on European Union (European Union, 2007). Furthermore, solidarity among the Member States is mentioned in the Treaty also in the context of external EU relations, area of freedom, security and justice, asylum and migrations, economic policy and energy, finally in Title VII devoted to solidarity clause as well as in the Charter of Fundamental Rights (Ibidem).

Alredy in 2007, before the financial and economic crisis, however, still in the process of ratification of the Treaty of Lisbon, solidarity as one of the most important European values was underlined in speeches of the most important European officials. Barroso (2007), President of the European Commission, in his speech in Warsaw, placed a lot of impact on solidarity as a condition of tackling main challenges of the 21 st century, he also named this value as a core of the European project.

Not all scientists agree on solidarity being one of the main values of the EU and even if, it is described as a horizontal rule complementary towards peace, human rights, democracy, and liberty (Williams, 2010). This approach gives even more theoretical ground for solidarity to be instrumentally used by the Member States, as it is subordinate towards peace and, particularly, security dominating national political debates in the context of the crises in the EU (Lahav \& Guiraudon, 2010).

Solidarity can be analyzed in the context of the EU crises as well as in the light of the pursuit of competitive advantage in the EU from numerous points of view. First of all, it is not the single value and the approach separated from such other aspects as responsibility or co-ordination. Secondly, an important question is still whether the rule of solidarity is just a moral rule to be used in crisis situations or it is a serious legal obligation in any situation in which the Member States prefer their own national interest rather than realization of important EU purposes or solving difficult EU problems (Raspotnik et al., 2012). In the scientific literature, it is difficult to find the opposite approaches, it is, however, necessary to mention that some of the authors do underline that the EU as a whole cannot stick to the solidarity rule rather than make it less important and find other basis for anti-crisis measures (Moravcsik, 2012). Although the rule of solidarity is mentioned expressis verbis in the Treaty of Lisbon (and in previous EC/EU treaties) that was also provided for as a guarantee of both implementation of the EC and then EU goals as well as abstaining Member States from actions pointed solely towards protection of national interests and undermining the overall interest of the Communities and then the EU (European Union, 2007). Taking all of that into consideration, political decisions of numerous Member States in different crises faced by the EU put into question the rule of solidarity and provoke to deep consideration both the EU institutions and other Member States. Such an example can be Greece regarding economic crisis, Eastern European countries regarding the immigration crisis or United Kingdom regarding Brexit. Considering the question of resistance of Polish, Czech, or Slovak authorities towards refugees and immigrants' quotas as a means of tackling the EU immigration crises, these Member States seem to forget that within the Multi-annual Financial Framework 2014-2020, they have become the largest beneficiaries of the structural support within the EU regional policy. Financial support from the EU budget should lead to strong development of these countries' competitive advantage on European scale and, indirectly to increase of meaning of the whole EU on the global market. However, with numerous expenses on the level of the whole 
EU and immigrants-friendly Member States (e.g. Germany, Sweden, France, and Belgium) as well as with steady terrorist threat in those Member States, it can be difficult to raise investments in innovativeness and modern technologies. This is an example of visible problems in understanding and implementing rule of solidarity in the EU in the light of strengthening the EU on the global market.

Solidarity as a value naturally refers to community, strong cooperation, and mutual understanding, therefore it may seem far from intuitive to put it in the context of an intergovernmental approach towards European integration, however, one should take here into consideration a very specific situation of examining the solidarity value - a situation of the largest and longest-lasting set of crises challenging the EU as the most efficient available mechanism of tackling tough crises in the Member States. Solidarity has capitulated to the pressure of the Member States regarding providing security and quick solutions to their citizens' fears.

Intergovernmental theory, which is also identified as realism and its more modern version-neorealism, has defined European integration in terms of international cooperation and as a collaboration which may at any time be interrupted, in which the most important reasons for staying within the common entity are related to separate interests of the Member States (while others are secondary) (Rosamond, 2002).

Crises have challenged the trust of citizens in the European Union, particularly when taking into consideration of the fact that a part responsibility for the crises has been put directly on the EU institutions. This has created conditions for governments in the Member States to regain influence on tackling the crises and has encouraged radical political parties to use this "wave of renationalization" in the European integration process to raise nationalistic and anti-European postulates. As a result of this process, intergovernmental perspective on European integration has got strengthened, which has negatively influenced belief of the EU citizens in such European values: a solidarity, community, and peace. In times of crisis, in particular in perspective of the internal differentiation of interests among the Member State, political concern grows to ensure the efficiency of measures of dealing with the crisis perceived from the national perspective, particularly in the non-Eurozone countries. Therefore, such approaches, hitherto dominating in the debated on the European integration, as neofunctionalism (Haas, 1958, pp. 16-27; Risse, 2005), institutionalism (particularly rational choice institutionalism and constructivism) (Checkel, 2001; Moravcsik, 2001), Multi-Level Governance (Hooghe \& Marks, 2001, pp. 2-4), or community method have lost their explanatory power of the integration processes and phenomena.

Despite the fact that the whole concept of the European Communities has been based on pursuit of economic and social welfare, only at the end of the 20th and at the beginning of the 21st century, the EU has realized a necessity of achievement of competitive advantage on global arena. In March 2000, for the first time in the history of the European Communities, a socio-economic strategy of achieving EU's competitive advantage was signed by the Member States. The strategy consisted of such elements as innovation, market liberalization, enhancing entrepreneurship, and social cohesion (The Lisbon Strategy, 2000-2010). The Lisbon Strategy was combined with the EU Sustainable Development Strategy (this one was more oriented towards the UN approach regarding sustainable development). The Lisbon Strategy did not fulfil hope put in it (due to its problematically broad scope and far from fully efficient method of implementation (through the so called "open method of coordination"). Monitoring of the EU Sustainable Development Strategy also did not bring good news-GDP per capita had not raised significantly enough, gas emissions had not decreased to the expected level, and sustainable consumption and production had not become present all over the EU (Eurostat, 2009). This situation plus a failure of the Lisbon Strategy led to adoption of a new strategy of "intelligent and 
sustainable development contributing to social inclusion" (Europe, 2020; 2010). Furthermore, financial and economic EU crises ultimately ended dreams about achieving the Lisbon strategy and the EU Sustainable Development Strategy indicators in the future and their replacement by the new strategy Europe 2020 was oriented much less towards competitive advantage in its strictly market-related aspects and much more towards achieving sustainable development, social inclusion, and welfare as conditions to win the global economic battle. In this regard, taking into consideration the fact that the EU has not passed the Lisbon strategy exam having performed too bureaucratically, too little democratically, and too slowly, Europe 2020 was instrumentally used by the Member States to explain some reforms to their citizens while the EU institutions have controlled fulfilling the indicators.

Despite the fact that numerous analysts point out rather little chance that the EU will gain competitive advantage globally soon, the process of implementation of the Europe 2020 strategy gives some incentives to the Member States to contribute to the European growth — not only to get oriented towards national economic interests. This may strengthen solidarity among the Member States particularly since "welfare", "sustainable development", and "inclusive social and economic policy" sound much more citizen-friendly than "market competitive advantage". So, in plain words, implementation of the Europe 2020 strategy is a field in which the EU Member States act intergovernmentally, however, with a constant awareness of a necessity for solidarity and cooperation in order to have any chance to grow globally and not to fall into a trap of economic isolation and lack of mechanisms of economic crisis management. However, understanding the importance of pursuit of economic cooperation and making efforts to strengthen European competitiveness on the global market do not mean that the Member States fully understand also the necessity for solidarity in managing the biggest crises faced by the EU. The Polish example of shifting from renewable and "clean" energy towards coal-based energy production at the end of 2015 and at the beginning of 2016 is an example of lack of understanding for strong cooperation in order to protect energy and environmental sustainability (Krasuski, 2016). However, plans of Nord Stream II from the EU to Russia (supported by Germany, Austria, the Netherlands) or South Stream do not give evidences of a large energy solidarity in the EU either (Bloomberg, 2016).

\section{Research Methods}

The crises EU has been facing for numerous years have undermined the value of solidarity of the Member States in its both political as well as economic dimensions. The rule has lost its power as a lighthouse of the European integration and has begun serving as an instrument of pressure in intergovernmental bargaining.

Community method with its finalite politiqué being a federal European state has lost its meaning and potential, various types of institutionalisms, and particularly constructivism have been treated as suitable only for the academics while intergovernmentalism, particularly in its liberal version, has become a proper lens for observing efforts of the EU Member States to defeat the crises. Solidarity does not seem to be the strongest value from the point of view of the intergovernmental approach, however, each of the EU crises has challenged it to a different extent.

All this has led to a meaningful, negative though, shift from pursuit of achieving competitive advantage in global economy, based on positive incentives from the EU towards the Member States to contribute to enhancement of innovation and economic development, towards fight for regaining full control over political decisions regarding economic development and defeating financial an economic crises. This, obviously, means stepping back in the European integration and puts into question both the issue of stronger and more efficient 
economic and political cooperation within the EU as well as coordination and responsibility in the light of making decisions related to fulfill the strategy Europe 2020. The shift towards more national and less European perspective regarding defeating the crises and developing economically also strongly challenges the future of the Eurozone as a political project.

Taking the above-mentioned phenomena into consideration, it is worth mentioning that in the financial programming period 2014-2020, the EU has seemed to try to find a balance between two main paradigms of pursuing of innovativeness and achieving competitive advantage, namely, (1) Supporting large scientific and innovative projects of experienced companies and scientific centres from mainly so-called old Member States or. (2) Investing more money in development of hitherto less experienced entities from the new Member States. The financing in this programming period has been provided to structural, scientific, and innovative technological projects through such main instruments as: structural funds, Horizon 2020, projects within the European Space Agency and others. The first approach may lead to better-quality and revolutionary large-scale innovative projects which might contribute to winning the competition with large American or Chinese companies and research institutes. The second approach might strengthen overall economic indicators of the EU Member States and enhance capacities to further implement innovative solutions in the Member States (particularly in the new ones). It seems, on the basis of the programs distributing financial support in the 2014-2020 financial framework, that the European institutions have tried to achieve a sort of a compromise and in certain aspects the first approach prevailed (regarding distribution of funds within European Research Area and Horizon 2020) while in others the second approach was chosen (in distribution of structural funds). This choice does not seem to give much hope on a turn in striving for competitive advantage giving additional speed to the EU. It is also worth mentioning that for implementation of the first approach - more promising regarding competitive advantage - it is foreseen about 80 billion EUR, while for the second one-more oriented towards support for the poor Member States - it is foreseen about 960 billion EUR. The disproportion is enormous.

So, despite the fact that those three issues, namely, solidarity value, intergovernmentalism as an approach towards the EU integration, and finally pursuit of European competitive advantage on global economic stage seem not to have that much in common, this paper is designed to examine an importance of all of them for finding a proper way of modernizing the EU towards its more efficient and more democratic functioning as well as quicker and more effective managing future crises in order not to fully lose the pursuit of competitive advantage in the global economy. Shortly speaking, intergovernmentalism appeared as a result of weakening of the EU non-intergovernmental institutions in tackling the main EU crises and it has dethroned other approaches not only regarding scientific analysis of the EU but also perception of the Member States.

The paper has been designed to shortly answer a few main research questions, namely: (1) To what extent have the EU crises strengthened the shift towards intergovernmental approach in the EU integration? (2) How has the meaning and scope of the solidarity as the main EU value changed over time in the EU's citizens' perception due to the EU crises? (3) To what extent have strong intergovernmental approach and instrumentalization of the solidarity value influenced pursuit for competitive advantage in the EU? (4) Does solidarity as an important European value have a potential to contribute to efficient reform of the European Union leading to strengthening its striving for competitive advantage in the future?

The answers will be elaborated on the basis of an in-depth analysis of the solidarity value as both legal and axiological basis of the European integration in difficult times of crises as well as on the basis of examination of stronger and stronger intergovernmental approach towards the EU integration as well as impact of this 
process on the EU efforts to gain competitive advantage on global economic stage. The analyses will be conducted on the basis of the following crises having challenged the EU as a whole and the Member States: economic crisis, migration crisis, and security crisis. Brexit will be here just an emanation of the overall problem of solidarity and intergovernmental shift in the EU integration. The dominating research method will be a process-tracing method supported by systemic analysis.

\section{Research Results}

Financial and then economic crises in the EU have undermined the EU's dream of becoming the most competitive economy in the world. Despite the fact that other large world economies have also faced major difficulties, the EU as a set of individual Member States could not quickly and efficiently undertake measures suitable for all the Member States and resulting in strengthening the whole EU. An important aspect of the crises was the division within the EU resulting from the fact of existence of the Eurozone and a group of Member States staying outside of the Eurozone. The latter, among them Poland, have used natural devaluation of their currencies to tackle the crises more efficiently, however, now they show much less motivation to adopt euro in the near future and risk the two-speed Europe.

Instruments of fighting against the economic crisis affected the entire EU and the Eurozone, but the effects of their application needed to be clearly visible for each country separately in order to satisfy citizens' expectations. This strengthened intergovernmental perspective, resulting in a number of Eurozone countries (i.e. Estonia and Slovakia) opposing to the instruments of solidarity towards the most vulnerable countries (Greece, Portugal, and Spain). The opposition was based on a sense of being used in the name of actual implementation of particular interests of Germany, France, and the Benelux countries (interested in constant trade with the countries in difficulty being their important export markets). Not only solidarity as a value was put to the test the context of the economic crisis but also less attention was paid to the neighborhood policy and security of the EU external surroundings. This led to less awareness in the context of the changes in North Africa and the emerging migration crisis.

It is obvious that the economic crisis strongly undermined the EU's economy, however, much less known result of the crisis is also much smaller GDP share of the world total. Just to make it clear, in 2007 GDP share of world total of the EU was $20.86 \%$, of the United States was $18.30 \%$, while of China-11.27\%. In 2016, this share has meaningfully changed and one of the EU is $16.71 \%$, of China- $17.65 \%$, of the United States-15.70\% (Economy Watch, 2016).

Eastern European EU Member States are reluctant towards the migrants quota system and show hardly any solidarity with those Member States which have been affected by the migrants' influx the most. The main reasons for that are strongly rooted in both already pointed out shift towards nationalization of anti-crisis measures leading to strengthening intergovernmental approach towards the EU as well as instrumentalization of the solidarity as a European value perceived by the Eastern European citizens as a tool of rich western countries' pressure on them leading to deepening inequalities among the Member States. So, despite increase of negative attitudes towards immigrants from the outside of the EU in majority of the Member States, roots of this process seem to be different in Western and in Eastern EU Member States. Taking into consideration political discourse regarding migration crisis in Eastern European countries, it is necessary to mention that the EU strategy on that matter has been perceived as dictated by Germany (BBC News, 2016). For example, Estonian government has faced the biggest debate in the history of this country's integration with the EU 
regarding solidarity and importance of protecting national interests in the face of the migration crisis.

A seriousness of the migration crisis can be seen on the basis of Figures 1 and 2 below pointing out attitudes of the citizens of the EU Member States towards immigration of people from outside of the European Union. Fairly or very negative attitude towards immigration grew meaningfully over a year (since 2014) in the whole EU, particularly in Eastern European countries perceiving debates over European solidarity in the context of this particular crisis as instrumentalization of this important European value for the sake of Germany and those EU Member States which might benefit or at least lose the least if they accept the immigrants. It is also worth mentioning that the discourse in the EU Member States about political meaning of the problem of migration for Chancellor Merkel or Scandinavian politics only confirms suspicions of the Eastern European countries that solidarity may not be absolute and universal if they need support and it is not politically meaningful for any of these Member States.

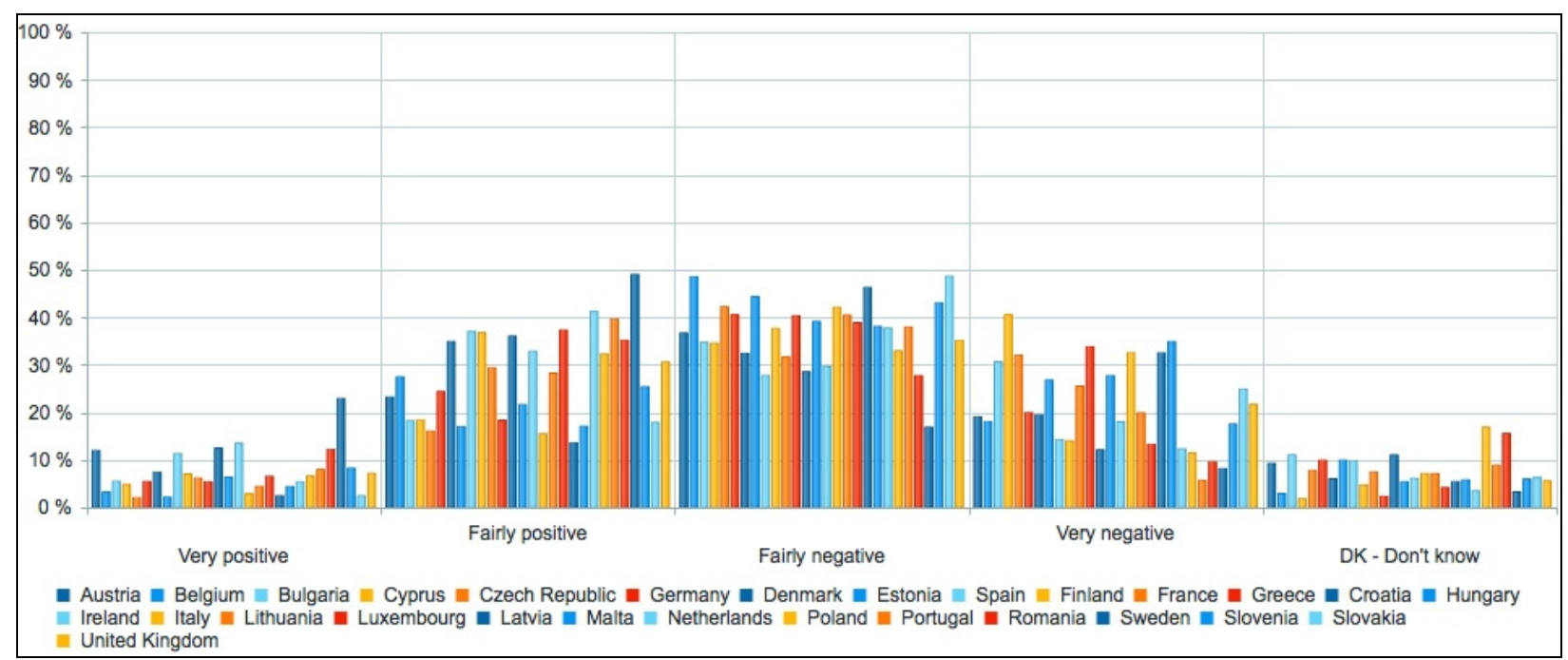

Figure 1. Attitude of the EU Member States' citizens towards immigration of people from outside of the EU (11/2014).

Source: Eurobarometer 2015.

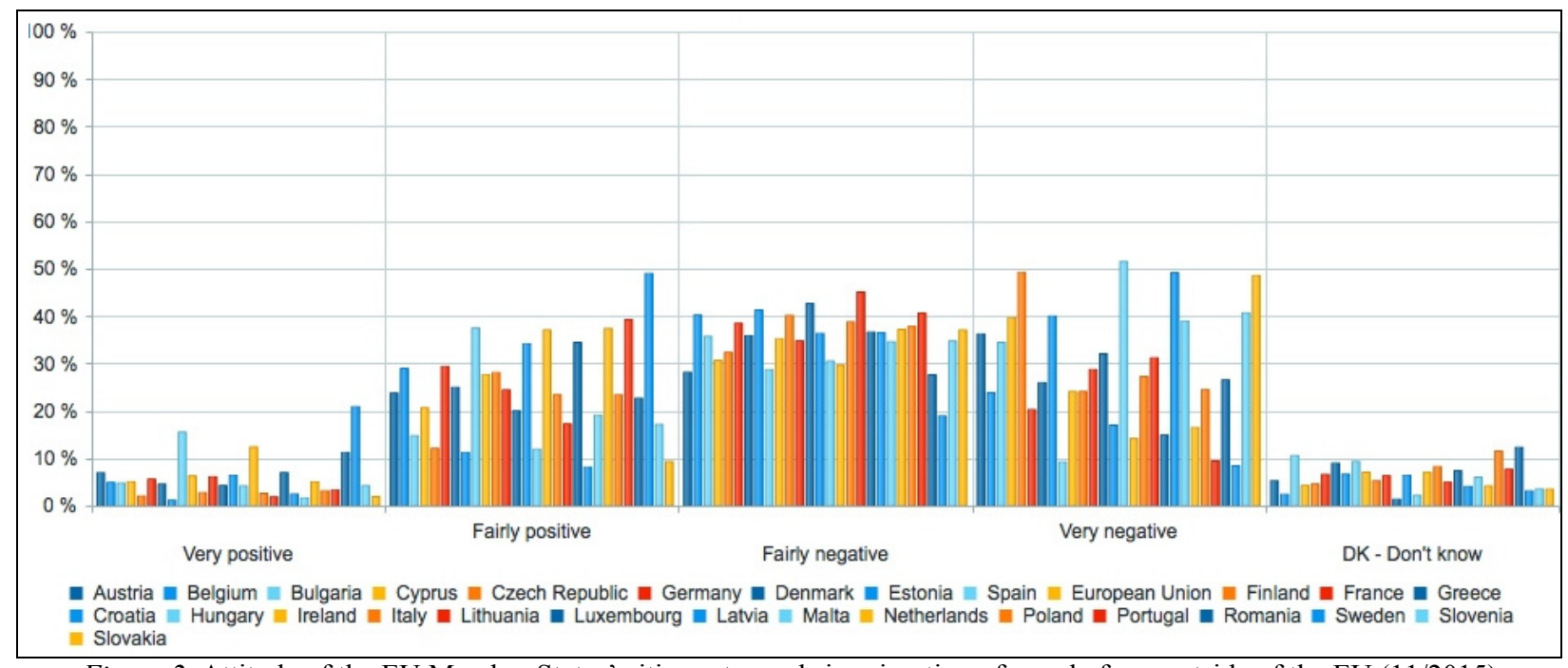

Figure 2. Attitude of the EU Member States' citizens towards immigration of people from outside of the EU (11/2015).

Source: Eurobarometer 2015. 
To explain the meaning of Figures 1 and 2 above, it is also necessary to add a country background of the voting for against the immigration of people from outside of the EU. It is worth mentioning that the most negative attitudes in this case are typical for homogeneous societies (in particular from Eastern Europe) while positive attitudes are related with hitherto experience of specific societies with immigrants and are typical for heterogeneous societies (e.g. British, German, and Swedish societies). To some extent, the data above can be also explained by taking into consideration fears of the societies mostly negative towards immigrants related to necessity of bearing large costs of maintenance of the immigrants in their countries. The European Commission tried to defeat this fear by devoting a specific budget (about 250 thousand EUR for every accepted refugee and immigrant), however, it did not seem to be convincing for the Eastern European Meber States having achieved a level of not more than $80 \%$ of the EU GDP average and making this financial data a strong argument in their internal political debates.

The question of Brexit has resulted from the previous EU crises, however, it was strengthened by instrumental use of solidarity rule by Germany (mainly) to solve its economic and political problem. The United Kingdom has always challenged the EU in a situation of growing meaning of Germany and weakening sense of community among the Member States. In this regard, however, it seems that the most important factor of Brexit as an emanation of the EU solidarity crisis is the fact that internal political reasons decided about such an important aspect of the EU integration.

The crisis of security in the European Union is strongly related to the immigration crisis, however, it has also another-Eastern dimension, namely, the problem of Russian-Ukrainian conflict and Russia's unpredictability regarding its role in fighting the Islamic State and supporting Syrian president—Bashar al-Assad as well as cooperating with other countries in this regard. Recent event in Nice-a terrorist attack organized by the ISIS supporter - as well as consequences of a failed coup d'etat in Turkey - a member of NATO and Council of Europe - have undermined the sense of safety among citizens of the European Union's citizens. Hardly, visible and ambigual reactions of the EU towards these events, particularly towards Turkey's president's actions embracing purges in public administration, at universities, in courts, in the army (tens of thousands of people were caught and put behind bars), have made the EU even less reliable and meaningful as organization which could at least try to deal with the question of security in Europe. It is worth mentioning, however, that the EU has a tough problem with Turkey for it is an ally of the EU in fighting the migration crisis (BBC News, 2016). Additional problematic aspect of the terrorist threat and the situation in Turkey is related to the fact that a vast majority of the EU Member States are also members of NATO (as Turkey is, having second largest army in the North Atlantic Treaty Organization). Destabilization of Turkey may also destabilize the whole NATO. Furthermore, one of the two main candidates for the post of the President of the USA-Donald Trump, announced that he would set up certain conditions if the US were to support their allies within NATO (Sanger \& Haberman, 2016). This has caused additional concerns, particularly in Eastern European EU Member States-traditionally allies of the United States in their security policy on international scale (e.g. Poland or the Baltic States). These concerns have been also related to the fact that not all of these states have already fulfilled the condition set up in the North Atlantic Treaty regarding spending at least $2 \%$ of their GDP to strengthen their military security.

The security crisis has shifted the interest of the EU as well as its Member States' from placing impact on economic (mainly structural and technological) development towards more awareness about security matters and international policy. This has, obviously, slowed down realization of the strategy Europe 2020 and made the process of striving for competitive advantage of the EU on global market less efficient. Even the fact that 
the EU Member States being also NATO members needs to spend at least 2\% of the GDP on security, may cause that those of them which do not fulfil this condition will cut the expenses in the field of research development and devote them to military budgets.

\section{Analysis and Discussion}

The EU requires deep modernization and full redefinition of its main goals, values, and strategies both internally and taking into consideration its position in global political and economic relations. The EU needs to modernize its Europe 2020 strategy towards more incentives for the Member States to implement it as an indispensible element of national economic strategies, oriented not only towards solidarity instrumentally used by stronger and richer countries to require more contribution from the more vulnerable ones but also towards solidarity as political argument for citizens of every EU Member State convincing them about grounding for rational and common goals-driven cooperation of all EU Member States where there is no impression of domination of any of them. Competitive advantage in the $\mathrm{EU}$ is not just a matter of pursuit of conquering space or building robots. It is also about enhancing capacities of healthcare in the EU, providing better care for elderly people in the EU, using renewable energy resources, preventing environment from irreversible pollution and many other aspects of contributing to the European welfare and competing with such countries as the USA, China, South Korea, or Japan in providing services based on innovative technological developments. Scientific and technological development of the EU and its Member States, no matter whether more in the light of the paradigm of supporting more advanced Member States or the model supporting less developed ones, should immediately come back on the list of priorities of the EU despite the above-mentioned crises. Furthermore, the main aspects of the strategy Europe 2020 should be included into the main measures of tackling the crises challenging the EU and all of the EU Member States should solitarily set up their own conditions for efficient implementation of the Europe 2020 priorities. This requires strong leadership in the European Commission and in the European Council (and more responsibility in this regard on the side of Jean-Claude Juncker and Donald Tusk) as well as strong and attractive incentives sent to the Member States to convince them of necessity of deeper concern regarding efficient implementation of the strategy of achieving competitive advantage by the EU on the global market. Such incentives should be based on the value of solidarity and particularly the poorer EU Member States should feel that they are supported by richer Member States and the EU institutions on this matter. This might also bring an added value for the EU, namely, it could contribute to decrease of nationalistic and anti-European sentiments in the Member States.

Also modernizing the EU solidarity needs to gain new, common meaning for all the Member States and this meaning (maybe pointed out expressis verbis in a new treaty) needs to embrace responsibility of stronger and richer Member States for the poorer without impression that this responsibility works only if these states may obviously benefit from it. Overwhelming impression in the EU that there is a specific dictate of Germany (or German-French-Belgian triangle) in the EU decision-making process (whether within the European Council or solely on bilateral or multilateral basis) will always put solidarity into question and will undermine any dreams about modernized and solidary EU able to manage any crisis.

\section{Conclusions}

It seems that solidarity has been recently neither a fully forgotten value in the EU nor is panacea to the EU crises, particularly bearing in mind its broad meaning and tendencies of the Member States to its instrumental 
use. However, when newly defined, it has a large potential of becoming a cornerstone for the reformed European Union and a basis of the new set of priorities leading to strengthening pursuit of the EU competitive advantage on the global market. This value may become a new axiological framework for the EU to perceive not only as an intergovernmental cooperation maintained to protect multiple national interests but also as an entity able to efficiently manage both internal and external crises the EU may face in the future. The EU's dreams of competitive advantage expressed in the Europe 2020 strategy have not been fully buried, however, in order to make them reality, not only solidarity value needs to be redefined and strengthened but also strong incentives for the Member States to become aware of the necessity of investing into modern technologies should be put in place by the EU leaders. This may not be easy in the light of the crises faced by the EU, however, it does not mean that this is fully impossible to be done.

\section{References}

Barroso, J. M. D. (2007). Playing as a team: The key to Europe's future, speech delivered during the Business Centre Club Award gala. Retrieved from ec.europa.eu/polska/documents/news/barroso_speech_en.doc

BBC News. (2016). Migrant crisis: EU-Turkey deal comes into effect. Retrieved from http://www.bbc.com/news/world-europe-35854413

Bloomberg. (2016). Europe doesn't need another Russian pipeline. Retrieved from https://www.bloomberg.com/view/articles/2016-02-18/germany-s-planned-nord-stream-2-gas-pipeline-to-russia-must-go

Checkel, J. (2001). Constructing European Institutions. In M. Aspinwall and G. Schneider (Eds.), The rules of integration: Institutionalist approaches to the study of Europe. Manchester: Manchester University Press.

Economy Watch. (2006). GDP share of world total (PPP) section of Economy Watch.com's Econ Stats database. Retrieved from $\mathrm{http}$ //www.economywatch.com/economic-statistics/economic-indicators/GDP_Share_of_World_Total_PPP/2016/

Ekathimerini.com. (2016). Tsipras decries lack of EU solidarity on refugees. Retrieved from http://www.ekathimerini.com/206142/article/ekathimerini/news/tsipras-decries-lack-of-eu-solidarity-on-refugees

Euronews.com. (2016). Erdogan defies EU on death penalty: "If Turkey's parliament backs it, I will". Retrieved from $\mathrm{http} / /$ www.euronews.com/2016/07/19/erdogan-defies-eu-on-death-penalty-if-turkey-s-parliament-backs-it-i-will

Europe 2020. (2010). Europe 2020, a strategy for smart, sustainable and inclusive growth. Brussels, 3.3.2010 COM (2010) 2020 final, Communication from the Commission.

European Union. (2007). Treaty of Lisbon Amending the Treaty on European Union and the Treaty Establishing the European Community. Retrieved from http://www.refworld.org/docid/476258d32.html

Eurostat. (2009). Sustainable development in the European Union-2009 monitoring report on the EU sustainable development strategy. $\quad$ Retrieved from http://ec.europa.eu/eurostat/documents/3217494/5703739/KS-78-09-865-EN.PDF/7ccc9240-03ae-40da-b2d8-2cc8a28df320

Faiola, A., \& Birnbaum, M. (2012). Germany offers vision of federalism for the European Union. Washington Post.

Haas, E. (1958). The uniting of Europe: Political, social and economic forces 1950-1957. Stanford: Stanford University Press.

Hooghe, L., \& Marks, G. (2001). Multi-level governance and European integration. New York, Oxford: Oxford University Press.

Krasuski, K. (2016). Poland's Government resists a clean-energy transition. IEEFA Publication. Retrieved from $\mathrm{http}$ //ieefa.org/though-polands-government-resists-a-clean-energy-transition-customers-still-want-it/

Lahav, G., \& Guiraudon, V. (2010). Actors and venues in immigration control: Closing the gap between political demands and policy outcomes. In V. Guiraudon and G. Lahav (Eds.), Immigration policy in Europe the politics of control (pp. 1-25). New York: Routledge.

Marks, G., Hooge, L., \& Blank, K. (1996). European integration from the 1980s. Journal of Common Market Studies, 34(3), 341-378.

Moravcsik, A. (2001). Bringing constructivist integration theory out of the clouds: Has it landed yet? European Union Politics, 2(2), 226-249.

Moravcsik, A. (2012). Europe after the crisis. How to sustain a common currency. Foreign Affairs, 91(3), 54-68.

Raspotnik, A., Jacob, M., \& Ventura, L. (2012). The issue of solidarity in the European Union. Discussion Paper for the TEPSA Pre-Presidency Conference 14-15, June 2012, pp. 1-2. 
Risse, T. (2005). Neofunctionalism, European identity, and the puzzles of European integration. Journal of European Public Policy, 12(2), 291-309.

Rosamond, B. (2002). Theories of European integration. In J. Gover(Ed.), The European Union Handbook, New York.

Sanger, D., \& Haberman, M. (2016). Donald trump sets conditions for defending NATO Allies against attack. New York Times. Retrieved from http://www.nytimes.com/2016/07/21/us/politics/donald-trump-issues.html?_r=0

The Economist. (2015). A walk down solidarity street the migration crisis will test one of Europe's dearest values. Retrieved from http://www.economist.com/news/europe/21654064-migration-crisis-will-test-one-europes-dearest-values-walk-down-solidari ty-street

The Lisbon Strategy. (2000-2010). An analysis and evaluation of the methods used and results achieved. A document of directorate general for Internal Policies Policy Department A: Economic and scientific policy employment and social affairs IP/A/EMPL/ST/2008-07 PE 440.285, 31-43.

Williams, A. (2010). The ethos of Europe: Values, law and justice in the EU. Cambridge: Cambridge Studies in European Law and Policy/Cambridge University Press, pp. 22-238. 